\title{
Wykorzystanie metod nieniszczących do oceny połączeń klejowych stosowanych w budowie nowoczesnych pojazdów szynowych
}

\author{
Use of non-destructive methods for assessing the adhesive \\ joints used in construction of modern railway vehicles
}

\section{Streszczenie}

W referacie zaprezentowano możliwości zastosowania metod nieniszczących, w szczególności metody ultradźwiękowej do oceny jakości połączeń klejowych stosowanych w budowie nowoczesnych pojazdów szynowych. W pierwszej kolejności przedstawiono charakterystykę i zastosowanie samych połączeń klejowych. W dalszej części przedstawiono ogólną charakterystykę metod oceny jakości tych połączeń - z podziałem na metody nieniszczące oraz metody niszczące. Szczególny nacisk położono na ultradźwiękową metodę oceny połączeń klejowych ze względu na jej potencjalną możliwość wykorzystania we współczesnym przemyśle. W pracy przedstawiono również aparaturę ultradźwiękową wykorzystywaną do badań połączeń klejowych znajdujących zastosowanie we współczesnych pojazdach szynowych oraz przykładowe wyniki badań połączenia dwóch stalowych elementów za pomocą żywicy epoksydowej.

Słowa kluczowe: badania nieniszczące; pojazdy szynowe; połączenia klejowe
Abstract

In this paper the possibility of using non-destructive methods, in particular ultrasonic method to evaluate the quality of adhesive joints used in the construction of modern railway vehicles was presented. In the first place, the characterization and use of an adhesive joints was presented. Next, the general characteristics of methods for assessing the quality of these connections - divided on the non-destructive and destructive methods was shown. Particular emphasis was placed on the ultrasonic method for assessing the adhesive joints because of its potential ability to use in today's industry. In the article was also shown an apparatus for ultrasonic testing of adhesive joints applicable in modern railway vehicles and results obtained during the test of connection of two metal parts with epoxy resin.

Keywords: non-destructive testing; railway vehicles; adhesive joints

\section{Wstęp}

Obserwując współczesne pojazdy szynowe, wyraźnie widać trend do zwiększania się udziału połączeń klejowych w ich budowie. Stopniowo odchodzi się od połączeń klasycznych, np. spawanych, czy zgrzewanych na korzyść połączeń adhezyjnych. Wynika to przede wszystkim z ich licznych zalet i niewielkich ograniczeń. Podstawowe zalety połączeń klejowych, które przyczyniają się do dynamicznego wzrostu ich zastosowania to obniżenie kosztów produkcji i uszczelnienie konstrukcji, brak konieczności posiadania specjalistycznych uprawnień przez pracowników wykonujących połączenia. Kleje doskonale tłumią drgania i jednocześnie zapewniają równomierny rozkład naprężeń w połączeniu - w przeciwieństwie do np. połączeń zgrzewanych. Główne ograniczania w zastosowaniu połączeń klejowych to przede wszystkim konieczność przestrzegania wysokiego reżimu technologicznego oraz niższa, niż w przypadku połączeń spawanych wytrzymałość mechaniczna. Jednym z istotnych ograniczeń, jaki cechują się połączenia klejowe jest trudność oceny nieniszczącej takich połączeń, w odróżnieniu od połączeń spawanych czy zgrzewanych. Badania połączeń spawanych są badaniami znormalizowanymi, funkcjonują procedury pozwalające na ich ocenę w warunkach przemysłowych. W przypadku połączeń zgrzewanych w warunkach przemysłowych funkcjonują najczęściej procedury i normy zakładowe, które umożliwiają ocenę wykonywanych połączeń, przy zastrzeżeniu, że takie procedury często stanowią utajnioną dokumentację producenta pojazdu.

We współczesnych pojazdach szynowych wykonywane jest wiele połączeń klejowych. Ze względu na wagę problemu dalsze rozważania zostaną ograniczone do połączeń konstrukcyjnych, takich jak połączenia wykorzystywane do łączenia poszycia, ścian bocznych, dachu, okien oraz podłogi do ramy. Przykładowe obszary, w których wykorzystuje się połączenia klejowe w pojazdach szynowych przedstawiono na rysunku 1.

Dr inż. Jakub Kowalczyk, dr inż. Wojciech Sawczuk, dr inż. Dariusz Ulbrich - Politechnika Poznańska

Autor korespondencyjny/Corresponding author. dariusz.ulbrich@put.poznan.pl 


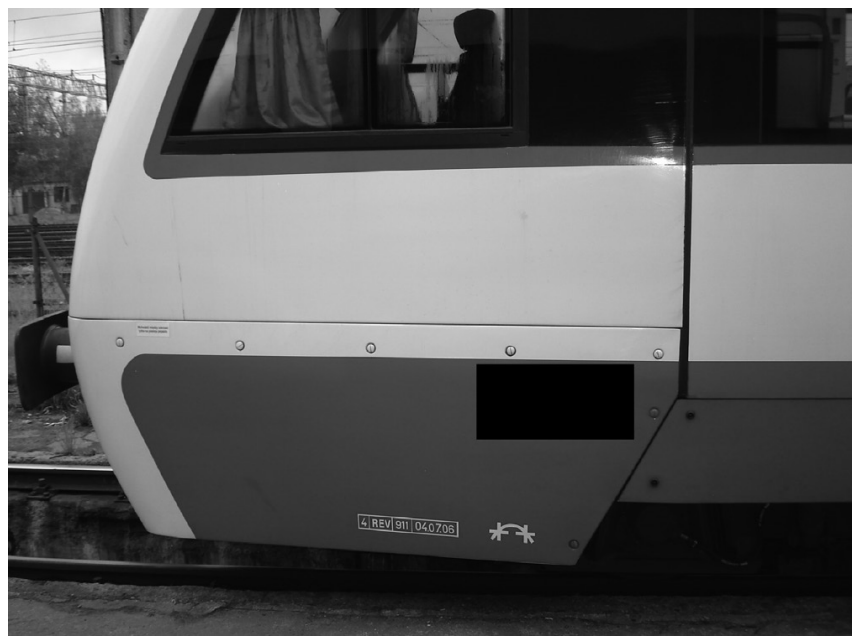

Rys. 1. Widok klejonego poszycia współczesnego pojazdu szynowego Fig. 1. View of the adhesive joint of modern rail vehicle

\section{Metody kontroli połączeń klejowych}

W laboratoriach zajmujących się zarówno połączeniami klejowymi, jak i kontrolą jakości produkowanych wyrobów funkcjonują powszechnie metody niszczące kontroli połączeń klejowych. Z jednej strony funkcjonują badania prowadzone wg przyjętych norm (np. ISO 37, ASTM D3166-99, DIN 54452) z drugiej zaś strony wykorzystywane są normy wewnętrzne producentów klejów, dla przykładu producent klejów Sika wykorzystuje procedury oznaczone jako CSQP - Corporate Sika Quality Procedure.

Badania niszczące umożliwiają ocenę jakości połączenia w różnych warunkach (zmienna temperatura, wilgotność, agresywne środowiska, zmienne obciążenia zmęczeniowe). Najprostsze badania niszczące, to badania wizualne w czasie których obserwuje się wypływkę kleju i na jej podstawie ocenia jakość połączenia. Nieco bardziej złożone badania to ocena obecności kleju i relacja między siłami adhezji a siłami kohezji (rys. 2).



Rys. 2. Ocena jakości połączenia klejowego - test podcinania [1] Fig. 2. Evaluation of adhesive joint quality - peeling test [1]

Zasadniczym ograniczeniem wykorzystania niszczącej kontroli połączeń klejowych jest całkowita degradacja połączenia klejowego. W praktyce ekonomicznie nieuzasadniona jest kontrola połączeń klejowych na obiektach produkowanych - przeznaczonych do sprzedaży.

W warunkach przemysłowych prowadzone są jedynie ograniczone, statystyczne badania połączeń klejowych, lub w przypadku procesów gwarancyjnych obiektów używanych. Związane jest to jednak ze znacznymi kosztami. Metody nieniszczące, które mogą być wykorzystywane do oceny połączeń klejowych to przede wszystkim takie metody jak: ultradźwiękowa, rezonansowa, termograficzna i metoda holografii optycznej [2]. Ponieważ au- torzy niniejszej publikacji, w swoich pracach badawczych kładą duży nacisk na badania przemysłowe w warunkach produkcyjnych, skoncentrowali badania w zakresie metody ultradźwiękowej. Wynika to zasadniczo, z faktu, iż większość producentów pojazdów szynowych, zarówno tych krajowych, jak i zagranicznych posiada aparaturę do badań ultradźwiękowych oraz przede wszystkim zatrudnia personel kwalifikowany do wykonywania znormalizowanych badań ultradźwiękowych. Dodatkowo metoda taka w opinii autorów umożliwia stosunkowo łatwe sparametryzowanie uzyskiwanych na ekranie defektoskopu ultradźwiękowego układów impulsów fali propagującej w obszarze połączenia.

W badaniach połączeń klejowych możliwe jest wykorzystywanie różnych defektoskopów ultradźwiękowych, przykładowe defektoskopy ultradźwiękowe wykorzystywane w badaniach ultradźwiękowych przedstawiono na rysunku 3.
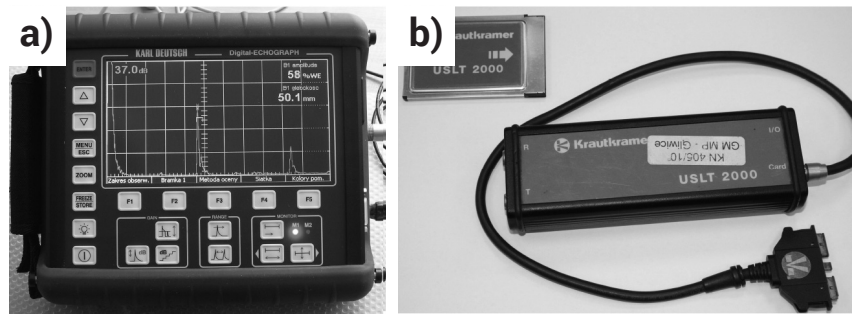

Rys. 3. Defektoskopy ultradźwiękowe wykorzystywane do badania połączeń adhezyjnych: a) Karl Deutsch, b) Krautkramer USLT2000 Fig. 3. Ultrasonic flaw detectors used for evaluation of adhesive joints: a) Karl Deutsch, b) Krautkramer USLT2000

Współczesne pojazdy szynowe są obiektami technicznymi o znacznym stopniu skomplikowania. Można wyróżnić w nich połączenia o niskiej i wysokiej podatności defektoskopowej. Połączenia o niskiej podatności defektoskopowej to przede wszystkim te połączenia, w przypadku których nie ma fizycznej możliwości przyłożenia głowicy ultradźwiękowej ponad obszar połączenia (np. połączenia podłogi do ramy pojazdu). Badania takich połączeń zostały przedstawione we wcześniejszej publikacji autorów [3], dlatego w niniejszej publikacji przedstawione zostaną rozważania związane z tymi połączeniami, nad którymi jest możliwość przyłożenia głowic ultradźwiękowych bezpośrednio do obszaru połączenia.

\section{Badanie wybranego połączenia klejowego}

Podstawowym parametrem akustycznym, który był wykorzystywany do oceny połączeń adhezyjnych w dotychczasowych badaniach [4] jest moduł ciśnieniowego współczynnika odbicia fali ultradźwiękowej podłużnej, odbitej od granicy połączenia adhezyjnego łączonych materiałów. Został on zaproponowany np. przez A. Pilarskiego w pracy [5]. Nie jest to jednak jedyny parametr przydatny do oceny stanu i jakości połączenia klejowego. Dlatego w niniejszej pracy, jako ultradźwiękową miarę jakości połączenia klejowego przyjęto decybelowy spadek wysokości impulsów z obszaru połączenia oraz dna badanej próbki.

Wybrane parametry impulsów fali ultradźwiękowej, wykorzystanej do badania połączeń klejonych, mogą być przydatne do oceny jakości tych połączeń. Korzystnym do oceny 


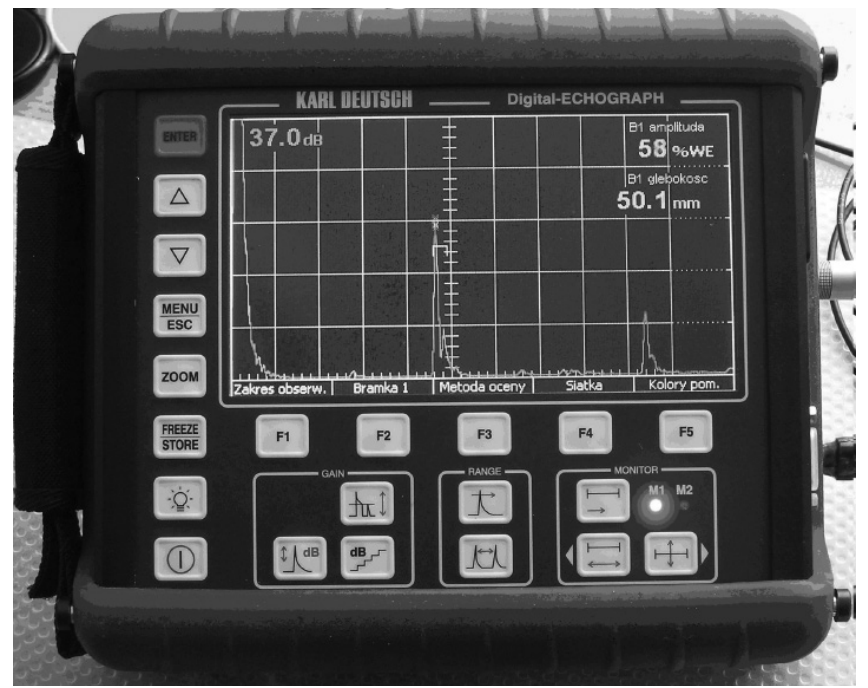

Rys. 4. Układ impulsów podczas badania połączenia klejowego o wysokiej jakości (widoczny brak impulsów z obszaru połączenia) Fig. 4. Ultrasonic pulses obtained during the test of very good quality adhesive joint (no pulses from joint area)



Rys. 5. Układ impulsów podczas badania połączenia klejowego o niskiej jakości (widoczny impuls odbity z obszaru połączenia) Fig. 5. Ultrasonic pulses obtained during the test of low quality adhesive joint (pulses from joint area) połączeń klejonych układem impulsów ultradźwiękowych na ekranie defektoskopu jest taki układ, w którym uzyskuje się dwa echa dna. Poniżej przedstawiono przykładowe układy impulsów na ekranie defektoskopu w czasie badania połączeń klejowych o wysokiej jakości (rys. 4) oraz niskiej jakości (rys. 5).

Po przeprowadzaniu pomiarów ultradźwiękowych, próbki zostały rozerwane. W czasie rozrywania dokonano pomiarów siły ścinającej - co pozwoliło na wyliczenia naprężeń. Próbki klejone miały w różny sposób przygotowaną powierzchnię, co pozwoliło na zróżnicowanie wytrzymałości mechanicznej połączenia.

Na rysunku 6 przedstawiono zbiorcze wyniki obrazujące zależność miary ultradźwiękowej (decybelowy spadek wysokości impulsów uzyskany na podstawie układów impulsów zobrazowanych na ekranie defektoskopu - np. rys. 4 i 5) i naprężeń ścinających, otrzymane podczas badań połączeń klejowego.

Po przeprowadzaniu pomiarów ultradźwiękowych, próbki zostały rozerwane. W czasie rozrywania dokonano pomiarów siły ścinającej - co pozwoliło na wyliczenia naprężeń. Próbki klejone miały w różny sposób przygotowaną powierzchnię, co pozwoliło na zróżnicowanie wytrzymałości mechanicznej połączenia.

$\mathrm{Na}$ rysunku 6 przedstawiono zbiorcze wyniki obrazujące zależność miary ultradźwiękowej (decybelowy spadek wysokości impulsów uzyskany na podstawie układów impulsów zobrazowanych na ekranie defektoskopu - np. rysunek 4 i 5) i naprężeń ścinających, otrzymane podczas badań połączeń klejowego.



Rys. 6. Wyniki badań ultradźwiękowych i mechanicznych połączeń klejowego

Fig. 6. Results of ultrasonic and mechanical testing of adhesive joints

\section{Podsumowanie}

Po przeprowadzeniu analizy oraz wykonaniu badań ultradźwiękowych można stwierdzić, że metoda ultradźwiękowa umożliwia badanie połączeń klejowych wykorzystywanych w nowoczesnych pojazdach szynowych, a wybrane parametry fali ultradźwiękowej można odnieść do naprężeń ścinających. W niniejszej publikacji rozważania ograniczono tylko do techniki ultradźwiękowej oraz zaprezentowano jedynie wybrane, przykładowe układy impulsów ultradźwiękowych uzyskane w trakcie realizacji badań na ekranie defektoskopu ultradźwiękowego oraz zestawiono wybrane wyniki dla oceny jakości połączenia klejowego dwóch elementów stalowych łączonych żywicą epoksydową.

\section{Projekt jest finansowany ze środków Narodowego Centrum Badań i Rozwoju, program LIDER V, umowa nr LIDER/022/359/L-5/13/NCBR/2014}

\section{Literatura}

[1] Sika Corporate Quality Procedure CQP033-1 - Bead Adhesion.

[2] Czaplicki J.: Klejenie tworzyw konstrukcyjnych, Wydawnictwa Komunikacji i Łączności, Warszawa 1987.

[3] Kowalczyk J., Jósko M.: badanie połączeń klejowych stosowanych w budowie autobusów metodą ultradźwiękową, 40 KKBN, Warszawa.
[4] Adams R. D., Drinkwater B. W.: Nondestructive testing of adhesively-bonded joints, NDT\&E International, Vol. 30, 2, 1997, pp. 93 - 98.

[5] Pilarski A.: Ocena wytrzymałości adhezyjnej połączeń warstwowych za pomocą metod ultradźwiękowych. Rozprawa doktorska, IPPT PAN, Warszawa 1983 (biblioteka IPPT PAN). 